\title{
Material Modeling of Hot-Rolled Steel Sheet Considering Differential Hardening and Hole Expansion Simulation
}

\section{Shunya Nomura ${ }^{1)}$ and Toshihiko KuwabarA ${ }^{2)^{*}}$}

1) Graduate School of Mechanical Systems Engineering, Tokyo University of Agriculture and Technology

2) Division of Advanced Mechanical Systems Engineering, Institute of Engineering, Tokyo University of Agriculture and Technology

Abstract: The elastic-plastic deformation behavior of a 440 MPa hot-rolled steel sheet subjected to many linear stress paths is precisely measured using biaxial tensile tests with cruciform specimens (ISO 16842: 2014) and multiaxial tube expansion tests (Kuwabara and Sugawara, 2013) to determine appropriate material models for finite element analysis (FEA). It was found that the Yld2000-2d yield function (Barlat et al., 2003) correctly reproduces the contours of plastic work (CPW) and the directions of the plastic strain rates (DPSR). Differential hardening $(\mathrm{DH})$ models are determined by changing the values of exponent and material parameters of the Yld2000-2d yield function as functions of reference plastic strain. Moreover, FEA of the hole expansion forming of the test material is performed. The DH model correctly predicts the minimum thickness position that matches the fracture position of the specimen in experiment.

Keywords: sheet metal forming; finite element method; hotrolled steel sheet; material modeling; differential hardening; hole expansion; fracture.

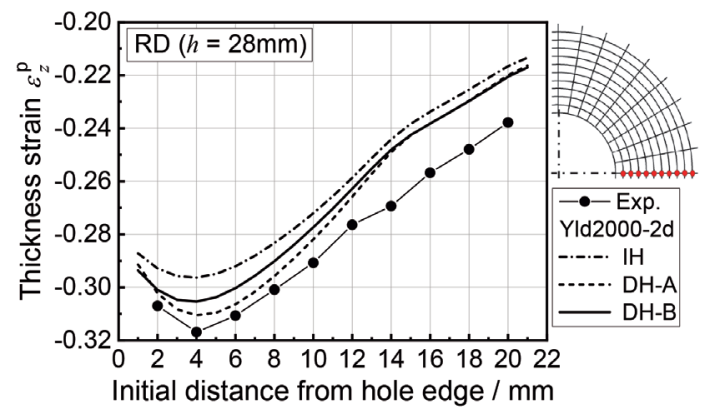

(a)

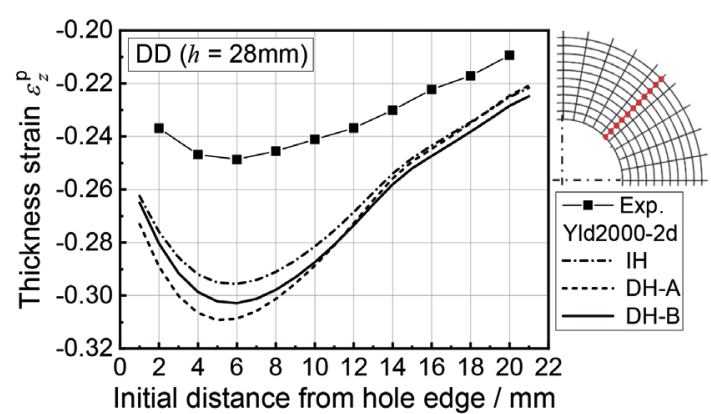

(b)

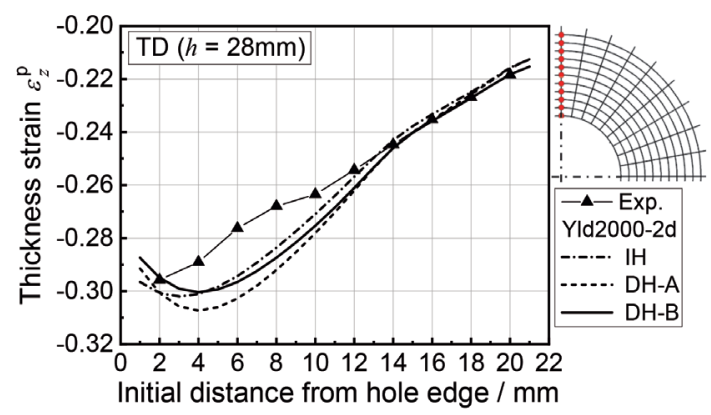

(c)

Received on Jan. 14, 2020 ; Accepted on Mar. 17, 2020 ; J-STAGE Advance published on Apr. 28, 2020

* Corresponding author. E-mail : kuwabara@cc.tuat.ac.jp, Address : Tokyo University of Agriculture and Technology, 2-24-16 Naka-cho Koganei Tokyo 184-8588 


\title{
異方硬化を考慮した熱延鋼板の材料モデリングと 穴広げ成形シミュレーション
}

\author{
乃村 峻矢 ${ }^{1)} \cdot$ 桑原 利彦 ${ }^{2) *}$ \\ Material Modeling of Hot-Rolled Steel Sheet Considering Differential Hardening and Hole Expansion Simulation
}

Shunya Nomura and Toshihiko Kuwabara

\section{1. 緒言}

自動車の足回り部品は高い応力が繰り返し負荷されるこ とから比較的厚肉な熱延鋼板が用いられているため, 車体 総重量の多くを占めていながら軽量化が遅れていだ。軽 量化のためには高強度材による薄肉化が有効だが, 高強度 化に伴う成形性の悪化によりプレス成形時に伸びフランジ 部での割れが頻発し問題となっている ${ }^{2)}$ 。そこで, 成形シ ミュレーションにより成形不具合を事前に予測し, 金型修 正工数を低減する試みが推進されている。成形不具合の予 測精度を向上させるためには, 材料の塑性変形挙動を再現 可能な高精度な材料モデルが必要である3)。

伸びフランジ成形の数值解析結果に及ぼす材料モデルの 影響に関する研究はいくつか報告されているが4-9)，いず れの研究に打いても解析に用いた材料モデルの妥当性が立 証されていないので, 計算結果の妥当性に疑義が残る。こ れまで筆者らの研究グループは, 十字形試験片を用いた二 軸引張試験法 ${ }^{10,11)}$ および円管材に大ひずみ二軸応力を発生 させる二軸バルジ試験法 ${ }^{12)}$ を考案し, 板材に対して適切な 材料モデルを決定する実験手法として活用してきた。そし て, 張出し成形 ${ }^{13)}$, 面ひずみ ${ }^{14)}$, 伸びフランジ成形 ${ }^{15,16)}$, 液 圧バルジ成形 ${ }^{17)}$ の成形シミュレーションにおいて, 適切な 降伏関数の選択が成形不具合の予測精度向上に必要不可欠 であることを立証してきた。最近, Suzuki ${ }^{18)}$ は, 固溶強化型 $440 \mathrm{MPa}$ 級熱延鋼板 (板厚 $2.0 \mathrm{~mm}$ ) と析出強化型 $590 \mathrm{MPa}$ 級熱延鋼板（板厚 $2.3 \mathrm{~mm}$ ) について穴広げ成形実験とその 有限要素解析を実施し, 高次降伏関数の方がHillの 2 次降 伏関数よりも板厚分布の予測精度に優れることを示してい る。この結果は筆者らの研究グループにおいて得られた上 記の知見と整合する。
成形シミュレーションでは, 降伏曲面が相似形状を保ち つつ拡張すると仮定して, 材料の加工硬化を定式化する材 料モデル (等方硬化 (Isotropic hardening: $\mathrm{IH}$ ) モデル ; 以 下IHモデル) が広く用いられている。しかし, 実際の材料 は加工硬化の進展に伴い降伏曲面の形状が変化すること が知られている。これは異方硬化 (Differential hardening: DH $)^{19,20)}$ と呼ばれ, 異方硬化を再現する材料モデル (以下 $\mathrm{DH}$ モデル $)^{21)}$ を用いることで, 成形シミュレーションの解 析精度向上が期待できる。筆者らはこれまで, アルミニウ ム合金板 ${ }^{22-24)}$ および鋼板 ${ }^{25)}$ に対して, 板材が破断するまで の大ひずみ範囲に対して二軸応力試験を実施し, Yld2000$2 \mathrm{~d}$ 降伏関数 ${ }^{26)}$ を用いた DHモデルを作成して成形シミュ レーションに適用することで, 解析精度が向上することを 示した。また, Tsutamori ら ${ }^{27}$ は 3 次スプライン降伏関数を 用いたDHモデルを作成し, 穴広げ成形解析の精度が向上 することを示している。

そこで本研究では, 熱延鋼板を対象として, 代表的な降 伏関数に基づく IH モデルに加えて, パラメータの決定方 法の異なる2 種類の DH モデルを構築し, 材料モデルが解 析精度に及ぼす影響をより詳細に検証することを目的とす る。研究の手法としては, 供試材の単軸抢よび二軸引張試 験データに基づいて, IH およびDHモデルを構築した。並 行して, 伸びフランジ成形を模擬する実験として穴広げ成 形実験を行い, 成形後の試験片の板厚分布を詳細に測定し た。さらに，作成した材料モデルを用いて穴広げ成形解析 を行い, 板厚分布を計算し, 実験值と比較した。その結果, DHモデルの適用は穴広げ成形に打ける破断予測の精度向 上に有効であることを明らかにしたので報告する。

2020年1月14日受付 2020年3月17日受理２020年4月28日J-STAGE早期公開 (Received on Jan. 14, 2020 ; Accepted on Mar. 17, 2020；J-STAGE Advance published on Apr. 28, 2020)

1) 東京農工大学大学院機械システム工学専攻 (Graduate School of Mechanical Systems Engineering, Tokyo University of Agriculture and Technology)

2) 東京農工大学大学院工学研究院先端機械システム部門 (Division of Advanced Mechanical Systems Engineering, Institute of Engineering, Tokyo University of Agriculture and Technology)

* Corresponding author. E-mail : kuwabara@cc.tuat.ac.jp, Address : Tokyo University of Agriculture and Technology, 2-24-16 Naka-cho Koganei Tokyo 184-8588 


\section{2. 実験方法}

\section{$2 \cdot 1$ 供試材}

供試材として公称板厚 $1.6 \mathrm{~mm}$ の $440 \mathrm{MPa}$ 級熱間圧延鋼 板を用いた。供試材の機械的性質を Table 1 に示す。以下, 異方性の主軸として, 圧延方向 (RD) を $x$ 軸, 板幅方向 (TD) を $y$ 軸, 板厚方向 $(\mathrm{ND})$ を $z$ 軸とする。また $\mathrm{RD}$ から $45^{\circ}$ 方向 をDDと記す。

\section{$2 \cdot 2$ 単軸引張試験}

JIS13B 号試験片を用いて RDから $15^{\circ}$ 毎に単軸引張試験 を行ない, $r$ 值および単軸塑性流動応力を測定した。以下, $\mathrm{RD}$ から $\theta^{\circ}$ 方向の単軸引張試験から測定される $r$ 值を $r_{\theta}$, 単 軸塑性流動応力を $\sigma_{\theta}$ と記す。

\section{$2 \cdot 3$ 二軸応力試験}

供試材の二軸応力状態における弾塑性変形挙動を精度よ く再現できる降伏関数を決定するために，十字形試験片に よる二軸引張試験 ${ }^{10,11)}$ および円管試験片による二軸バルジ 試験 ${ }^{12)}$ を行った。各試験片の寸法を Fig.1に示す。

十字形試験片の形状および試験方法はISO16842 20 に準 拠した。Fig.1に示す位置においてひずみゲージによりひず みを測定することにより, 応力の測定誤差を $2 \%$ 未満に抑 えられることが有限要素解析 ${ }^{28,29)} に よ り$ 確認されている。

二軸バルジ試験では，供試材をロール曲げして板縁を 突合せ溶接した円管試験片を製作した。RDを円周方向に とった試験片 I およびRDを管軸方向にとった試験片 II の 二種類を製作した。二軸バルジ試験法の詳細は文献 12）を 参照されたい。本試験法で測定された応力ーひずみ曲線 は，円管試験片製作時の曲げによる予ひずみの影響を含む ため，十字形試験片により測定した真応力ー対数塑性ひず み曲線により補正した。補正方法は文献12）を参照された い。

両試験共に, $\sigma_{x}: \sigma_{y}=4: 1,2: 1,4: 3,1: 1,3: 4,1: 2,1:$ 4 の7通りの線形応力経路にて実験を行った。ここで, $\sigma_{x}$ は $\mathrm{RD}$ 真応力, $\sigma_{y}$ は TD真応力である。相当塑性ひずみ速度は ほぼ $10^{-4} \mathrm{~s}^{-1}$ 一定となるように制御した。二軸バルジ試験 では，円管試験片の円周方向が常に最大主応力方向となる ように試験を行った。すなわち $\sigma_{x}: \sigma_{y}=4: 1,2: 1,4: 3$ では試験片 Iを, $\sigma_{x}: \sigma_{y}=3: 4,1: 2,1: 4$ では試験片 II 用いた。

Table 1. Mechanical properties of the test material.

\begin{tabular}{ccccccc}
\hline $\begin{array}{c}\text { Tensile } \\
\text { direction/ }\end{array}$ & $E / \mathrm{GPa}$ & $c^{*} / \mathrm{MPa}$ & $n^{*}$ & $\alpha^{*}$ & $\varepsilon_{\mathrm{TS}}^{\mathrm{p} * *}$ & $r^{* * *}$ \\
\hline 0 & 192 & 764 & 0.215 & 0.012 & 0.187 & 0.78 \\
\hline 45 & 203 & 756 & 0.234 & 0.023 & 0.191 & 1.06 \\
\hline 90 & 212 & 797 & 0.249 & 0.029 & 0.182 & 0.85 \\
\hline
\end{tabular}

* Approximated using $\sigma=c\left(\alpha+\varepsilon^{\mathrm{p}}\right)^{n}$ for $\varepsilon^{\mathrm{p}=0.002 \sim \varepsilon_{\mathrm{TS}}^{\mathrm{p}}}$

** Logarithmic plastic strain giving the maximum tensile load

$* * *$ Measured at a uniaxial nominal strain of $\varepsilon_{\mathrm{N}}=0.1$

\section{3. 二軸応力試験結果}

単軸打よび二軸応力状態における供試材の加工硬化挙 動を定量的に評価し，材料モデルの高精度化に資するため に, 等塑性仕事面 ${ }^{19,20)}$ を測定した。まず, RD単軸引張試験 により得られた真応力ー対数塑性ひずみ曲線において, 規 定の対数塑性ひずみ $\varepsilon_{0}^{\mathrm{p}}$ (以下, 基準塑性ひずみ) に達した 瞬間における単軸引張真応力 $\sigma_{0}$ と, $\varepsilon_{0}^{\mathrm{p}}$ に達するまでに消費 された単位体積あたりの塑性仕事 $W_{0}$ を求める。次に, 二軸 応力試験およびTD単軸引張試験から得られた真応力一対 数塑性ひずみ曲線において $W_{0}$ と等量の塑性仕事が消費さ れた時点の真応力 $\left(\sigma_{x}, \sigma_{y}\right)$ を求め, それらを主応力空間に プロットし，規定の $\varepsilon_{0}^{\mathrm{p}}$ に対する等塑性仕事面を決定した。 等塑性仕事面の測定結果を Fig. 2 に示す。単軸引張試験を 含め, 最大で $\varepsilon_{0}^{\mathrm{p}}=0.22$ までの等塑性仕事面を測定できた。

等塑性仕事面の形状変化 (異方硬化) を定量的に評価す るために, 等塑性仕事面を構成する応力点の值を当該の $\varepsilon_{0}^{\mathrm{p}}$ に対応する $\sigma_{0}$ で除して得られた無次元等塑性仕事面を求 めた。さらに, 各応力経路における形状比 $l / l_{0.02}$ を求めた。 ここで $l_{0.02}$ は $\varepsilon_{0}^{\mathrm{p}}=0.02$ に対応する $\left(\sigma_{x} / \sigma_{0}, \sigma_{y} / \sigma_{0}\right)$ までの原点 からの距離, $l$ は規定の $\varepsilon_{0}^{\mathrm{p}} に$ 対応する $\left(\sigma_{x} / \sigma_{0}, \sigma_{y} / \sigma_{0}\right)$ までの 原点からの距離である。二つの等塑性仕事面が相似であれ ば, すべての応力経路で形状比は 1 となる。 $\varepsilon_{0}^{\mathrm{p}} の$ 増加に伴 $う l / l_{0.02}$ の変化を Fig. 3 に示す。 $\varepsilon_{0}^{\mathrm{p}} \leq 0.02$ の範囲では材料の降 伏伸びの影響により等塑性仕事面の形状変化が不安定なた

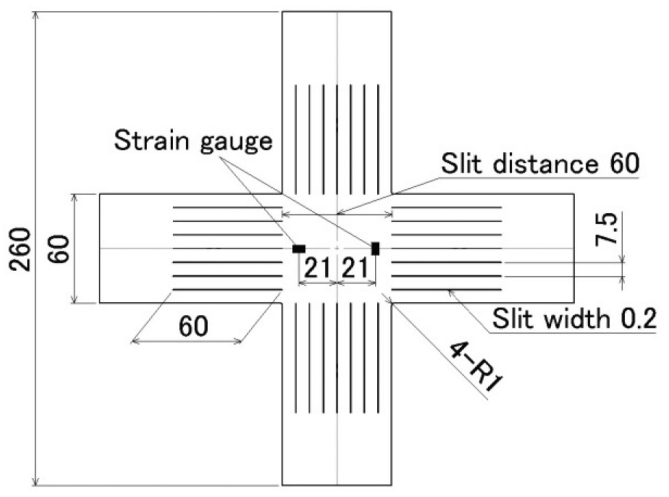

(a)

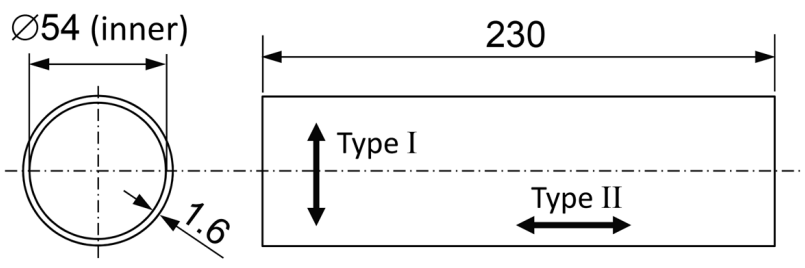

(b)

Fig. 1. Geometry of the specimens of (a) biaxial tensile test (ISO $16842)^{4)}$ and (b) multiaxial tube expansion test ${ }^{6)}$. $\leftrightarrow$ is the rolling direction of the original sheet sample. Units are in $\mathrm{mm}$. 
め省略した。 $0.02 \leq \varepsilon_{0}^{\mathrm{p}} \leq 0.05$ の範囲で $l / l_{0.02}$ は最大で $3 \%$ 変化 し, $\varepsilon_{0}^{\mathrm{p}}>0.05$ では概ね一定となる。以上より, 本供試材の 異方硬化挙動が定量的に評価できた。このような等塑性仕 事面の形状変化はIH モデルでは表現することはできない。

\section{4. 材料モデリング}

3節で測定された実験值に基づいて, von Mises ${ }^{30)}$, Hill の2次 (以下 Hill'48) (1) $^{31}$ よびYld2000-2d $\mathrm{d}^{26)}$ 降伏関数 (以 下Yld2000-2d）を同定し，IHモデルを作成した。さらに

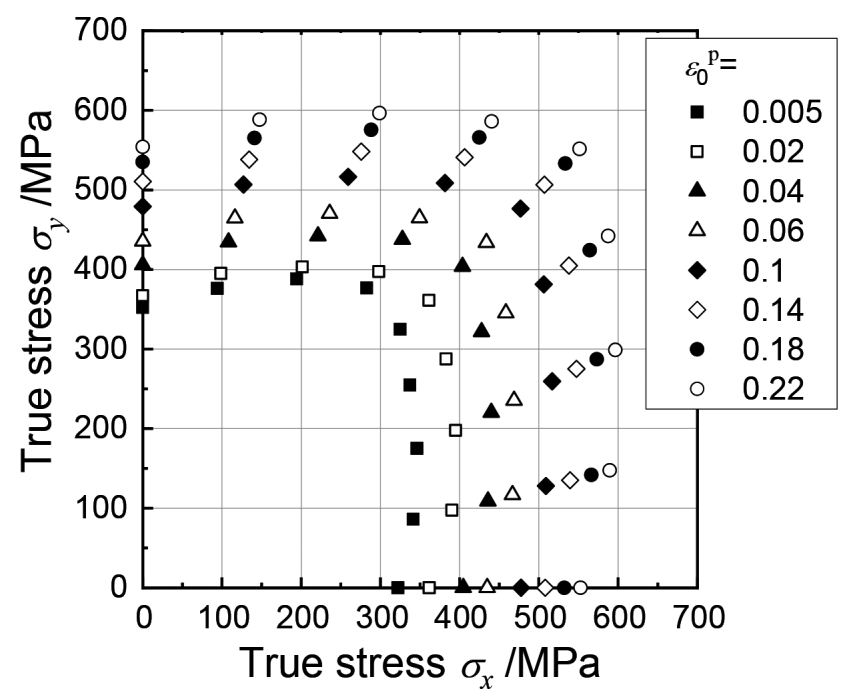

Fig. 2. Measured stress points forming contours of plastic work for different levels of $\varepsilon_{0}^{\mathrm{p}}$.
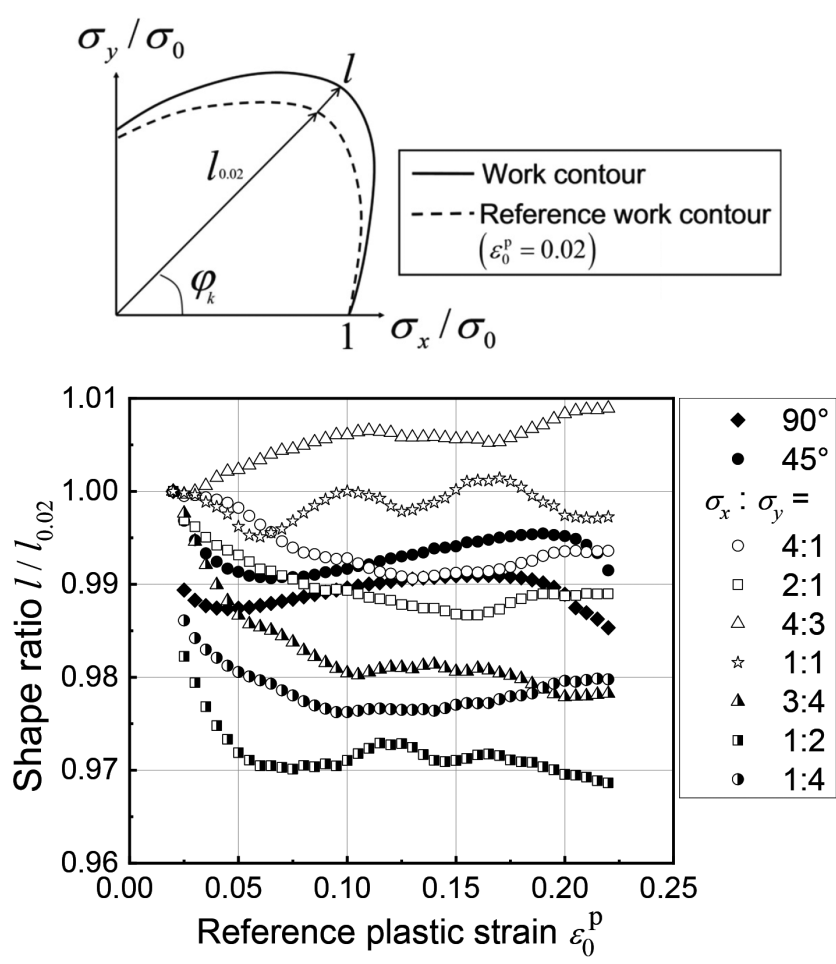

Fig. 3. Variation of the shape ratio, $l / l_{0.02}$, with the increase of $\varepsilon_{0}^{\mathrm{p}}$.
Yld2000-2dを用いてDHモデルを作成した。本節では各材 料モデルの作成方法について述べる。

$4 \cdot 1$ IHモデル

$4 \cdot 1 \cdot 1$ von Mises およびHill'48

von Misesの同定には $\sigma_{0}$ を, Hill'48 の同定には, $\sigma_{0}$ おび 公称ひずみ 0.10 に打ける $r$ 值 $r_{0}, r_{45}, r_{90}$ (Table 1 参照) を用 いた。以下, 本モデルを $r$-Hill'48 と記す。

$4 \cdot 1 \cdot 2$ Yld2000-2d

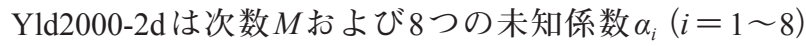
より決定される。IHモデルの作成では, 遺伝的アルゴリズ ム (Genetic algorithm：GA法) を用いて次式の評価関数 $f$ を 最小化する $M$ 打よび $\alpha_{i}(i=1 \sim 8)$ を決定した。

$$
f=\sum_{i=1}^{N} w_{\sigma, i}\left(l_{\mathrm{M}, i}-l_{\mathrm{C}, i}\right)^{2}+\sum_{i=1}^{N} w_{\beta, i}\left(\beta_{\mathrm{M}, i}-\beta_{\mathrm{C}, i}\right)^{2}
$$

第一項目はYld2000-2dから計算された降伏曲面と等塑性 仕事面 (実験值) との偏差を, 第二項目は塑性ひずみ速度 $\mathbf{D}^{\mathrm{p}}$ の方向の計算值と実験值との偏差の総和を表す。具体的 には， $l_{\mathrm{M}, i}$ および $l_{\mathrm{C}, i}$ は，それぞれ $i$ 番目の線形応力経路にお ける原点から無次元化等塑性仕事面および降伏曲面までの 距離を， $\beta_{\mathrm{M}, i}$ および $\beta_{\mathrm{C}, i}\left(\right.$ 単位: $\left.{ }^{\circ}\right)$ は，㶢れぞれ $i$ 番目の線形 応力経路に打ける $\mathbf{D}^{\mathrm{p}}$ の方向の実験值とYld2000-2dによる 計算値を表す (Fig.4参照)。 $w_{\sigma, i}, w_{\beta, i}$ は各応力経路に対する 重み係数であり,この係数を変更することで, 再現性を重 視する実験值を任意に選択することが可能である。本研究 において用いた $w_{\sigma, i}, w_{\beta, i}$ の值を Table 2 に示す。 $N(=14)$ は 応力経路の数であり,7方向 (RDから $15^{\circ}$ 毎) の単軸引張試 験および7線形応力経路の二軸引張試験から得られた実験 值を用いた。等塑性仕事面を構成する応力の実験值につい ては，単軸および二軸引張試験すべてにおいて， $\varepsilon_{0}^{\mathrm{p}}=0.22$ に打ける塑性流動応力を用いた。 $\mathbf{D}^{\mathrm{p}}$ の方向の実験值につい ては, 単軸引張試験に対しては公称ひずみ $10 \%$ における $r$ 值を, 二軸引張試験に対しては $\varepsilon_{0}^{\mathrm{p}}=0.22 に お け る$ 実験值を

Table 2. Weighting factors used in Eq.(1).

\begin{tabular}{|c|c|c|c|}
\hline \multicolumn{2}{|c|}{ Stress ratio $\sigma_{x}: \sigma_{y}$} & $w_{\sigma, i}$ & $w_{\beta, i}$ \\
\hline \multicolumn{2}{|c|}{$1: 0$} & 1000 & 1 \\
\hline \multicolumn{2}{|c|}{$4: 1$} & 1 & 5 \\
\hline \multicolumn{2}{|c|}{$2: 1$} & 1 & 0.1 \\
\hline \multicolumn{2}{|c|}{$4: 3$} & 1 & 0.1 \\
\hline \multicolumn{2}{|c|}{$1: 1$} & 10 & 0.1 \\
\hline \multicolumn{2}{|c|}{$3: 4$} & 1 & 0.1 \\
\hline \multicolumn{2}{|c|}{$1: 2$} & 1 & 5 \\
\hline \multicolumn{2}{|c|}{$1: 4$} & 1 & 0.1 \\
\hline \multicolumn{2}{|c|}{$0: 1$} & 100 & 1 \\
\hline \multirow{5}{*}{ Uniaxial } & $15^{\circ}$ & 1 & 0.1 \\
\hline & $30^{\circ}$ & 1 & 0.1 \\
\hline & $45^{\circ}$ & 10 & 3 \\
\hline & $60^{\circ}$ & 1 & 2 \\
\hline & $75^{\circ}$ & 1 & 2 \\
\hline
\end{tabular}


用いた。

\section{$4 \cdot 1 \cdot 3$ 実験值と IH モデルによる計算值の比較}

IHモデルにより計算された降伏曲面と等塑性仕事面の 比較を Fig.5 (a) に, $\mathbf{D}^{\mathrm{p}}$ の方向の比較を Fig.5 (b) に, $\sigma_{\theta}$ の分 布を Fig.5 (c) に， $r_{\theta}$ の分布をFig.5 (d) に示す。Yld2000-2d による計算值が全ての実験值を最も精度よく再現した。

\section{4・2 DHモデル}

DHモデルの作成では，ひずみの進展に伴う Yld2000-2d のパラメータ $M$ および $\alpha_{i}(i=1 \sim 8)$ の変化を, $\varepsilon_{0}^{\mathrm{p}}$ の関数と して近似した。 $M$ および $\alpha_{i}(i=1 \sim 8)$ の発展を関数近似す

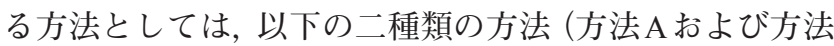
B）を用いた。方法A は文献 ${ }^{22)}$ で考案された方法である。す

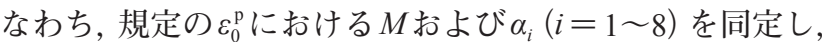
各パラメータを個別に $\varepsilon_{0}^{\mathrm{p}}$ の関数として近似する。しかし， この方法では $M$ 打よび $\alpha_{i}(i=1 \sim 8)$ が $\varepsilon_{0}^{\mathrm{p}}$ 毎に離散的に最適 化されるため, $\varepsilon_{0}^{\mathrm{p}}$ の増加に伴う連続的な発展を再現しつつ 最適化することが難しい。また，重み係数を変更する際に， その都度各 $\varepsilon_{0}^{\mathrm{p}}$ 毎のパラメータを同定する必要があるため, モデル作成に手間がかかる。そこで本報では新たに方法 $\mathrm{B}$

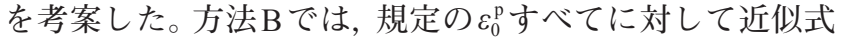
の最適化を同時に行うことにより，連続的なパラメータの 推移の最適化が可能となる。

\section{$4 \cdot 2 \cdot 1$ 方法 Aに基づく DH モデル（DH-A）の作成}

方法Aの手順を以下に記す。

i ) 規定の $\varepsilon_{0}^{\mathrm{p}}$ における $M$ および $\alpha_{i}(i=1 \sim 8)$ を決定する。 その決定手順は以下の通りである。次数 $M$ を 0.01 刻み に変化させ，その $M$ に対して 8 つの実験值（規定の $\varepsilon_{0}^{\mathrm{p}}$ における $\sigma_{0}, \sigma_{45}, \sigma_{90}$ および等二軸引張における流動応 力 $\sigma_{\mathrm{b}}$ と塑性ひずみ速度比 $r_{\mathrm{b}} \equiv \dot{\varepsilon}_{y}^{\mathrm{p}} / \dot{\varepsilon}_{x}^{\mathrm{p}}$, Table 1 に示す $r_{0}$, $\left.r_{45}, r_{90}\right)$ を用いて Newton-Raphson 法により $\alpha_{i}(i=1 \sim 8)$ を決定し，降伏曲面と実験值の䛊差を式 (1) の評価関 数 $f$ で計算し,$f$ を最小化する $M$ を決定する。ここでの 重及係数は一律 $w_{\sigma, i}=1, w_{\beta, i}=0.3$ とした。

ii ） i ）において得られた $M$ の変化を $\varepsilon_{0}^{\mathrm{p}}$ の関数として次式 で近似する。

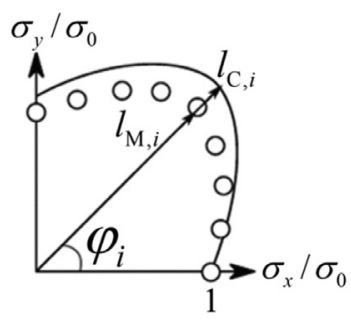

(a)

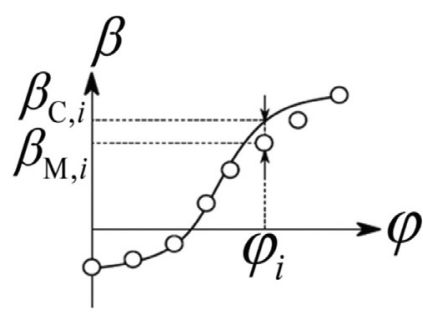

(b)
Fig. 4. Schematic illustrations for identifying the parameter of the Yld2000-2d yield function: (a) contour of plastic work and (b) direction of plastic strain rate. $\varphi_{i}$ is the angle of the $i^{\text {th }}$ linear stress path from the RD in the $\sigma_{x}-\sigma_{y}$ stress space.

$$
M\left(\varepsilon_{0}^{\mathrm{p}}\right)=(A-B) /\left[1+\exp \left\{\left(\varepsilon_{0}^{\mathrm{p}}-C\right) / D\right\}\right]+B
$$

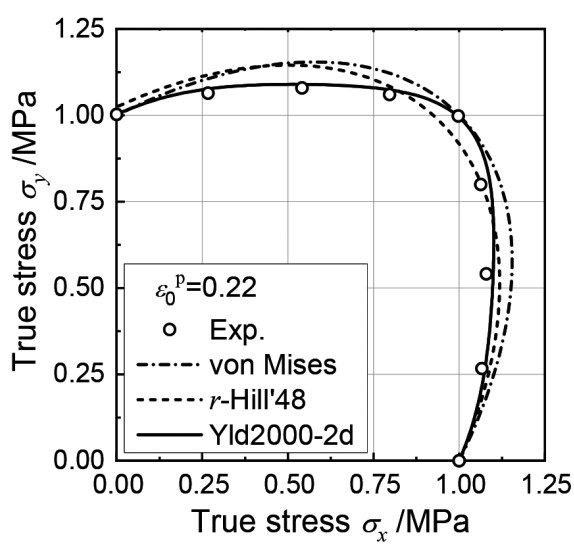

(a)

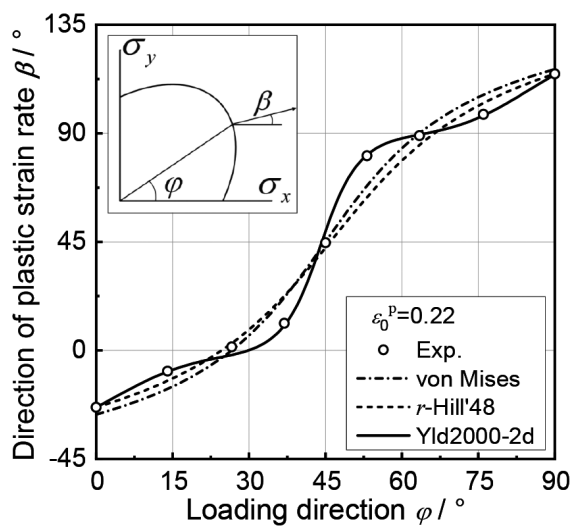

(b)

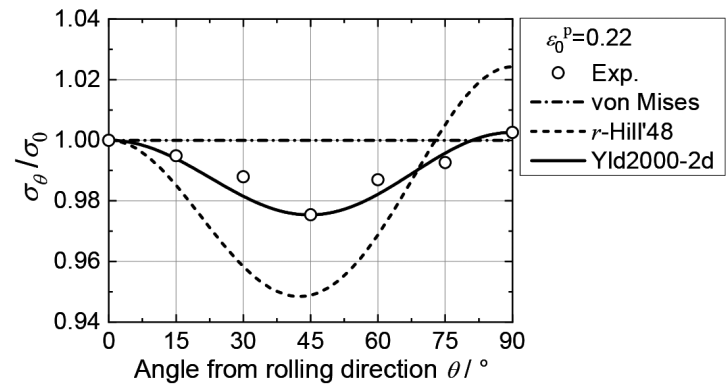

(c)

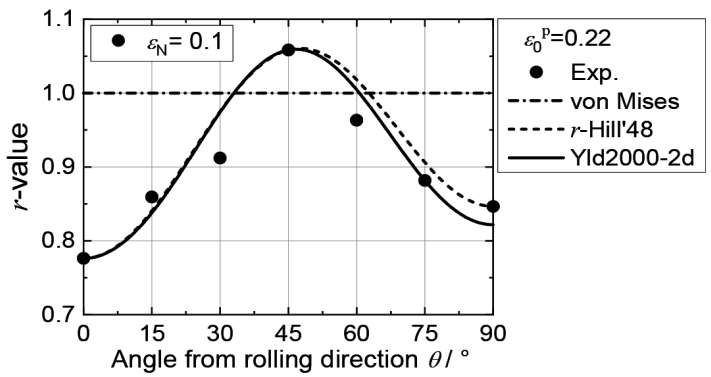

(d)

Fig. 5. Measured data of (a) the stress points forming contours of plastic work, (b) the directions of plastic strain rates, (c) uniaxial flow stresses, and (d) $r$-values, compared with those calculated using selected yield functions (IH model). 
iii）式（2）で近似された $M$ を用いて，各 $\varepsilon_{0}^{\mathrm{p}} に$ 対する $\alpha_{i}(i=$ 1〜8）をGA法により決定する（計算方法は $4 \cdot 1 \cdot 2$ 節 と同一)。

iv） iii）において得られた $\alpha_{i}(i=1 \sim 8)$ の変化を $\varepsilon_{0}^{\mathrm{p}}$ の関数 として次式で近似する。

$$
\alpha_{i}\left(\varepsilon_{0}^{\mathrm{p}}\right)=A-B \exp \left(-C \varepsilon_{0}^{\mathrm{p}}\right)-D /\left(0.001+\varepsilon_{0}^{\mathrm{p}}\right)
$$

近似式 (2)，(3) に打ける係数 $A, B, C, D$ の值は Table $\mathrm{A} 1$ 觉照。

$4 \cdot 2 \cdot 2$ 方法 $\mathrm{B}$ に基づく DHモデル（DH-B）の作成 方法Bの手順を以下に記す。

i ) $4 \cdot 2 \cdot 1$ 節と同様の手順で $M$ および $\alpha_{i}(i=1 \sim 8)$ を $\varepsilon_{0}^{\mathrm{p}}$ の関数として次式で近似する。

$$
M\left(\varepsilon_{0}^{\mathrm{p}}\right), \alpha_{i}\left(\varepsilon_{0}^{\mathrm{p}}\right)(i=1 \sim 8)=A \varepsilon_{0}^{\mathrm{p}}\left(\varepsilon_{0}^{\mathrm{p}}-B\right) \exp \left(C \varepsilon_{0}^{\mathrm{p}}\right)+D
$$

ii ) 式 (4) の係数 $A, B, C, D$ を初期值として, 次式の評価 関数 $f_{\mathrm{B}}$ が最小となるように GA 法を用いて最適化した。

$$
f_{\mathrm{B}}=\sum_{j=1}^{m}\left\{\sum_{i=1}^{n} w_{\sigma, i}\left(l_{\mathrm{M}, i}-l_{\mathrm{C}, i}\right)^{2}+\sum_{i=1}^{n} w_{\beta, i}\left(\beta_{\mathrm{M}, i}-\beta_{\mathrm{C}, i}\right)^{2}\right\}
$$

係数 $A, B, C, D$ の数值は Table A2 を参照。

$4 \cdot 2 \cdot 3$ 実験值と DH モデルによる計算値の比較

$\mathrm{DH}$ モデルにより計算された降伏曲面と $\varepsilon_{0}^{\mathrm{p}}=0.005$ およ び0.22に打ける等塑性仕事面との比較を Fig.6 (a) に, $\mathbf{D}^{\mathrm{p}}$ の比較を Fig.6 (b) に, $\sigma_{\theta}$ の比較を Fig.6 (c) に, $r_{\theta}$ の比較を Fig.6 (d) に示す。参考としてYld2000-2dのIHモデルによ る計算値も併記する。DH-A およびDH-Bに付随する表記 $\left\lceil\varepsilon_{0}^{\mathrm{p}}=X\right\rfloor$ は, $\varepsilon_{0}^{\mathrm{p}}=X$ に対する実験值および計算値を表す。 $\mathrm{IH}$ モデルは $\varepsilon_{0}^{\mathrm{p}}=0.22$ における実験值を用いているため, $\varepsilon_{0}^{\mathrm{p}}$ $=0.005$ における実験值と乘離が見られる。DHモデルは, ひずみの増大に伴う等塑性仕事面と $\sigma_{\theta}$ の変化を精度よく

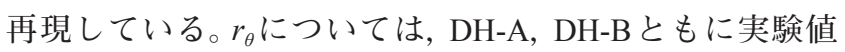
から若干の乘離があるものの, DDの $r$ 值が極大となる傾向 は定性的に再現できている。

\section{5. 穴広げ成形実験と有限要素法解析}

4節で作成した材料モデルを穴広げ成形シミュレーショ ンに適用し，板厚ひずみ分布の測定值と比較することによ り，作成した材料モデルの有用性を検証する。

\section{$5 \cdot 1$ 穴広げ成形実験}

穴広げ成形実験用金型の断面図を Fig.7 (a) に示す。直径 $215 \mathrm{~mm}$ の円形素板を使用し, ワイヤ放電加工により素板 中央に直径 $30 \mathrm{~mm}$ の穴を開けた。パンチ径は $100 \mathrm{~mm}$, パン チ肩拉よびダイ肩の丸み半径は $15 \mathrm{~mm}$ である。パンチスト ローク速度は $0.1 \mathrm{~mm} / \mathrm{s}$ とした。素板には, 円周方向に $10^{\circ}$,
半径方向に $2 \mathrm{~mm}$ ごとの格子をけがき, 試験後の板厚測定 における初期座標の特定に用いた。パンチと試験片の間に は両面にワセリンを塗布したテフロンシートを挿入し, 潤

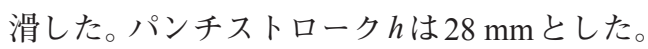

\section{$5 \cdot 2$ 穴広げ成形の有限要素解析}

有限要素解析には, 静的陰解法ソフトウェアABAQUS/ Standard 2017 を用いた。解析モデルの概要を Fig.7 (b) に示 す。金型は解析的剛体とし，素板には4 節点低減積分シェ ル要素S4Rを用い, 板厚方向の積分点数は 7 とした。素板 は対称性を考慮して $1 / 4$ モデルで解析を行った。素板の要 素は円周方向に $3^{\circ}$ 毎, 半径方向は $1 \mathrm{~mm}$ 毎に分割した。素 板の初期板厚は実験に用いた試験片の平均初期板厚である $1.574 \mathrm{~mm}$ とし, 初期穴径は $30 \mathrm{~mm}$ とした。ビード頂点部か らの材料流入はないものとして, 半径 $97.5 \mathrm{~mm}$ の素板外縁 上の節点変位を完全固定とした。摩擦係数は素板とパンチ 界面を 0.03 , 金型と素板界面を 0.2 とした。また, 加工硬化 式にはRDの単軸引張試験から同定されたSwiftの式 (Table 1参照)を用いた。

\section{$5 \cdot 3$ 計算值と実験値の比較}

$5 \cdot 3 \cdot 1$ IH モデル

初期素板上に打いて穴縁から半径方向へ $2 \mathrm{~mm}$ 離れた位 置における対数塑性板厚ひずみ $\varepsilon_{z}^{\mathrm{p}}$ の円周方向分布につい て, IHモデルによる計算值と実験值の比較を Fig.8に示す。 板厚ひずみの実験值は DDで極大, $\mathrm{RD}, \mathrm{TD}$ で極小, $\mathrm{RD}$ 最小となった。等方性を仮定しているvon Misesでは当然 ながら均一な板厚減少を示している。 $r$-Hill'48 は極大值と 極小值の位相が実験值と逆転しており，材料モデルとして の精度は低い。これに対してYld2000-2d は極值の位置は実 験值と一致している。しかしTDで最小值を予測しており, $\mathrm{RD}$ で最小となる実験の傾向を再現できていない。

$\mathrm{RD}, \mathrm{DD}, \mathrm{TD}$ 半径方向の $\varepsilon_{z}^{\mathrm{p}}$ 分布について, $\mathrm{IH}$ モデルに よる計算値と実験值の比較を Fig.9に示す。Yld2000-2dは $\mathrm{DD}$ において実験值とは最大で $\left|\Delta \varepsilon_{z}^{\mathrm{p}}\right|=0.05$ の差異がある が, $\mathrm{RD}$ とDでは実験值との差異は $\left|\Delta \varepsilon_{z}^{\mathrm{p}}\right|=0.02$ 以内であ り，実験值の傾向を全般的に精度よく再現できている。ま た RD, DDに打いて穴縁から4〜 $6 \mathrm{~mm}$ 離れた位置で極小值 をとる傾向も再現できている。

\section{$5 \cdot 3 \cdot 2$ DHモデル}

円周方向 $\varepsilon_{z}^{\mathrm{p}}$ 分布について, DH モデルによる計算値と実 験值の比較をFig.10に示す。DHモデルはDH-A, -Bともに RDで最小, TDで極小となりかつ実験值ともほぼ一致し ており，IHモデルよりも解析精度が向上したと言える。一 方, DH-A, -Bどちらのモデルも $\varepsilon_{z}^{\mathrm{p}}$ の振幅を過小評価して いる。また DDにおいては $\Delta \varepsilon_{z}^{\mathrm{p}}=0.05 \sim 0.04$ 程度板厚減少 を過大に予測している。DH-A と DH-Bの比較では, DH-B の方がわずかながら実験值に近い。

半径方向の $\varepsilon_{z}^{\mathrm{p}}$ 分布について, DHモデルによる計算值と 実験值の比較を Fig.11に示す。RD, DD, TDいずれの方向 


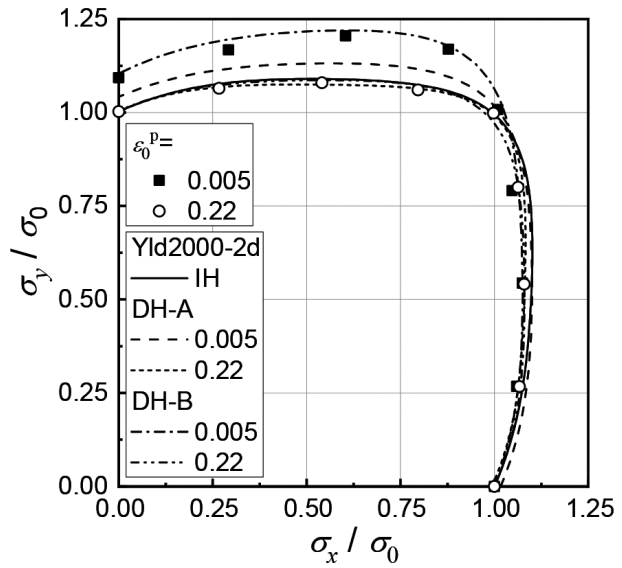

(a)

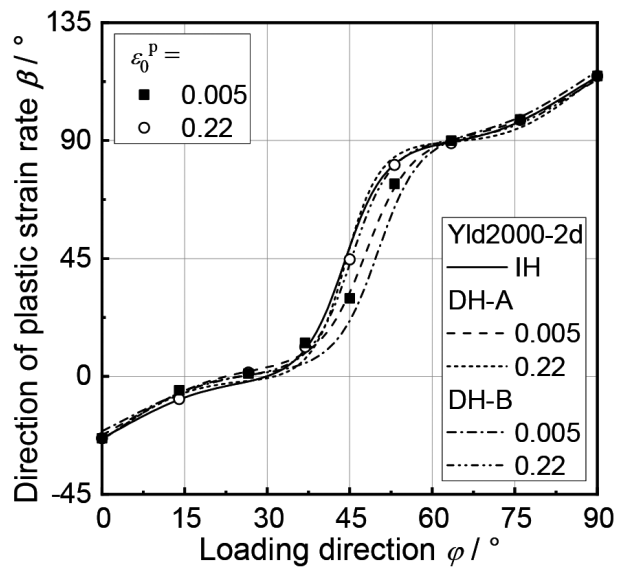

(b)

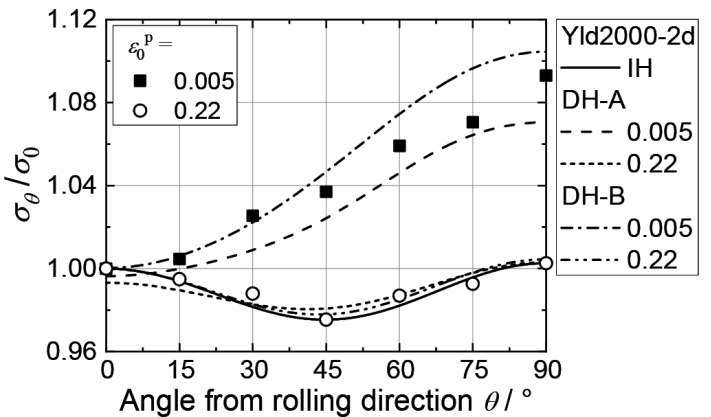

(c)

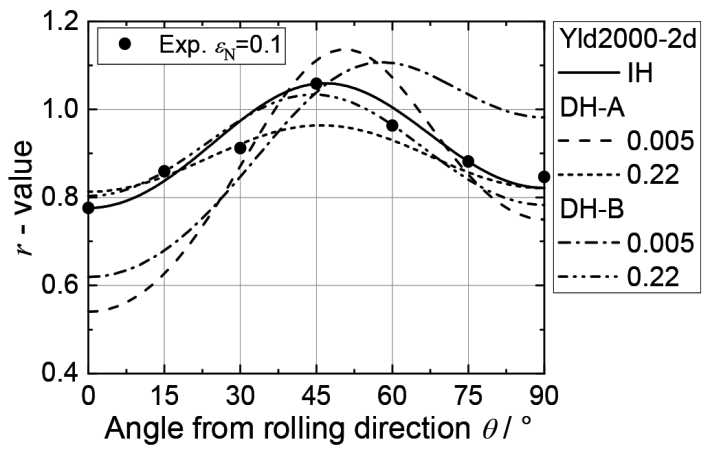

(d)

Fig. 6. Measured data of (a) the stress points forming contours of plastic work, (b) the directions of plastic strain rates, (c) uniaxial flow stresses, and (d) $r$-values, compared with those calculated using the Yld2000-2d yield function (DH model).

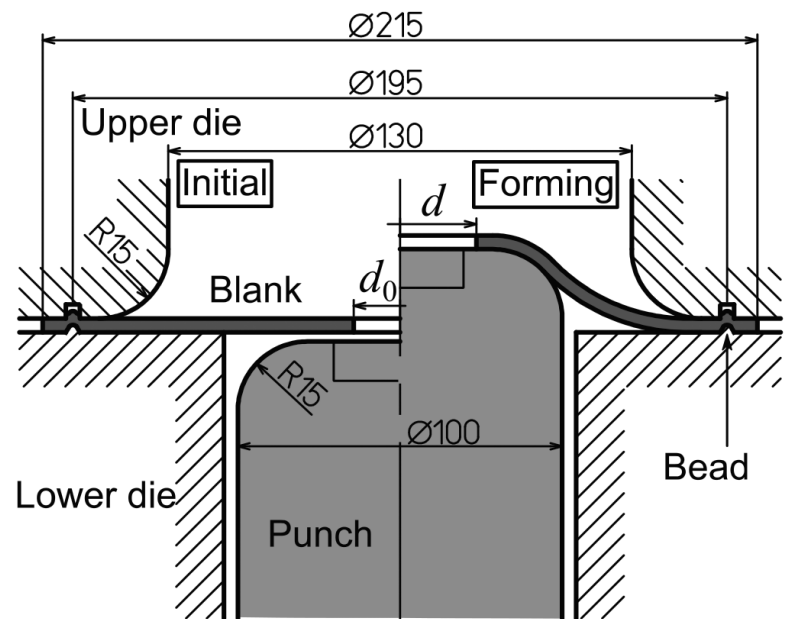

(a)

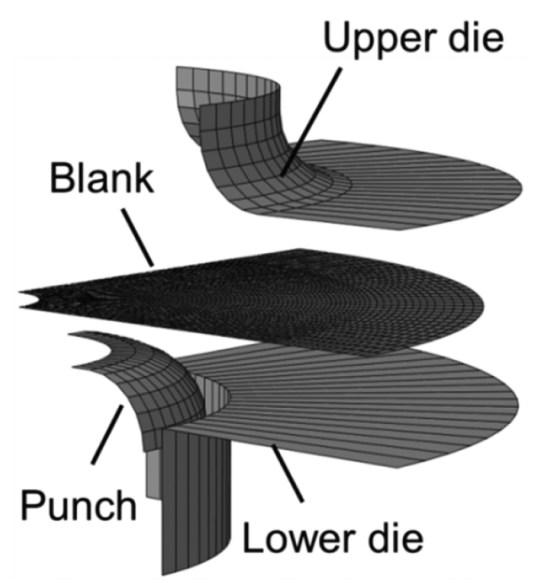

(b)

Fig. 7. Hole expansion forming: (a) geometry of the experimental apparatus and (b) quarter-model for finite element analysis (FEA).

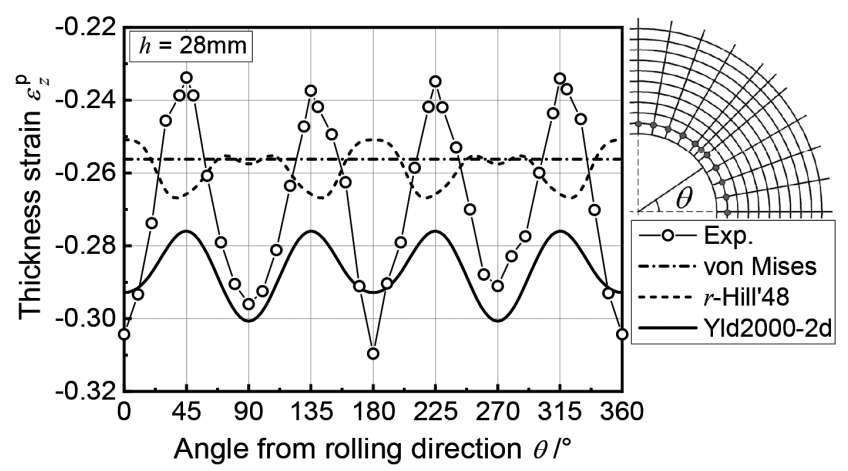

Fig. 8. Thickness strains along the expanded hole edge at a punch stroke of $28 \mathrm{~mm}$, compared with the FEA results (IH model). 
においても，3つの材料モデル（IH，DH-A，DH-B）間の差 異は $\Delta \varepsilon_{z}^{\mathrm{p}} \approx 0.01$ であり，実験值のばらつきと同程度である。 $\mathrm{RD}$ と $\mathrm{TD}$ では, どの材料モデルも $\Delta \varepsilon_{z}^{\mathrm{p}} \approx 0.005 \sim 0.03$ の䛊差 範囲で実験值の傾向を再現できている。RDではDH-Aが, TDでは IH と DH-Bが実験值に最も近い。一方, DDでは IH が実験值に最も近いものの，いずれの材料モデルも $0.02 \leq$ $\Delta \varepsilon_{z}^{\mathrm{p}} \leq 0.06$ の範囲で板厚減少を過大に予測しており, RD, $\mathrm{TD}$ よりも実験值からの乘離が大きい。以上のように, 半径 方向の $\varepsilon_{z}^{\mathrm{p}}$ 分布の予測精度については材料モデル間の優劣は つけ難い。

\section{$5 \cdot 4$ 考察}

穴広げ成形シミュレーションの結果を統括する。IHモ デル同士の比較では, Yld2000-2d が $\varepsilon_{z}^{\mathrm{p}}$ 分布の実験值を最も 精度よく再現した。さらにDHを再現するモデルの導入に より，穴縁における $\varepsilon_{z}^{\mathrm{p}}$ の最小位置を正確に再現することが 出来た。これは, $\mathrm{DH}$ モデルでは $\varepsilon_{0}^{\mathrm{p}}$ の増加に伴う $\sigma_{\theta}$ の円周 方向分布の発展が的確に再現されたためと考える。 $\sigma_{\theta}$ の実

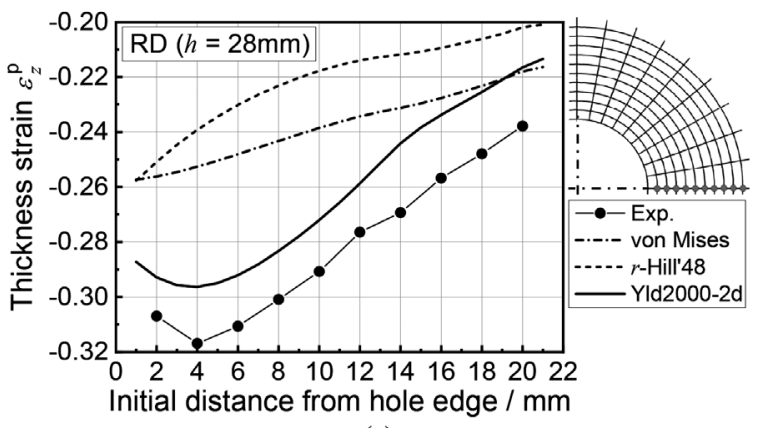

(a)

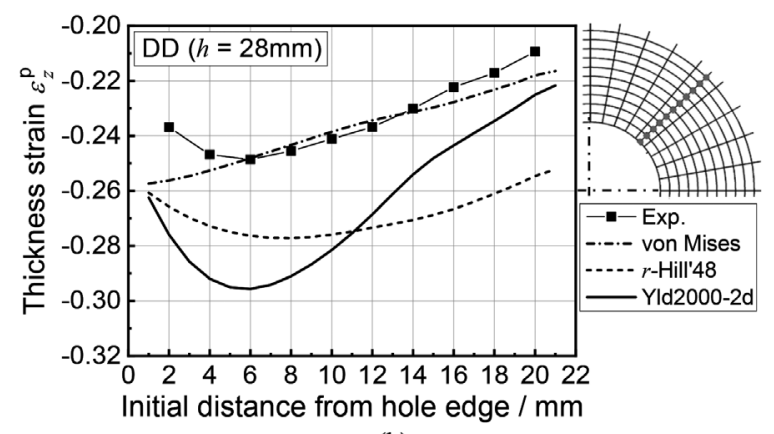

(b)

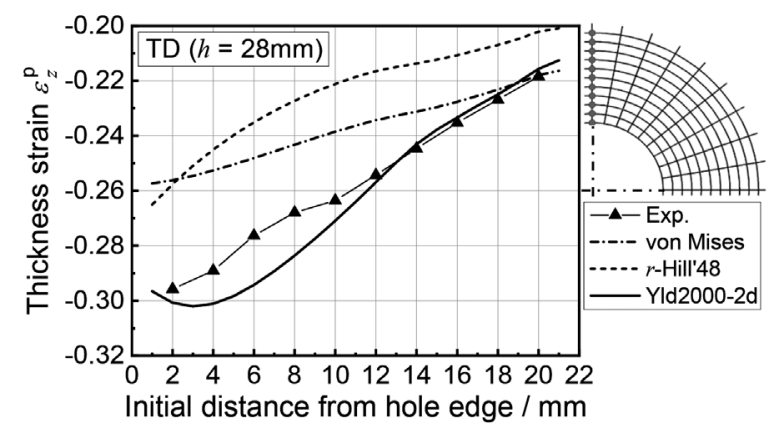

(c)

Fig. 9. Measured and calculated thickness strains along RD, $\mathrm{DD}$, and TD at a punch stroke of $28 \mathrm{~mm}$ (IH model).
験值と DH-B による計算值との比較を Fig. 12 に示す。 0.005 $\leq \varepsilon_{0}^{\mathrm{p}} \leq 0.01$ の低ひずみ範囲ではRDから TDにかけて $\sigma_{\theta}$ は単 調に大きくなるが， $0.02 \leq \varepsilon_{0}^{\mathrm{p}}$ では $\sigma_{\theta}$ はDDで最小となった。

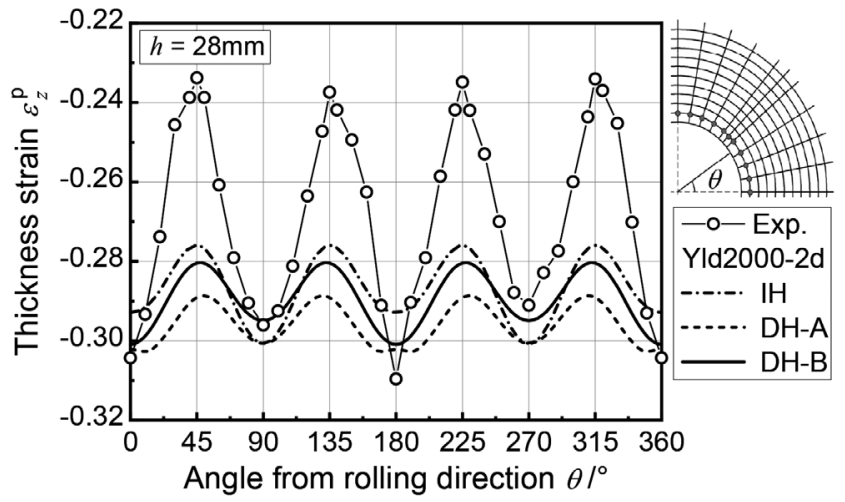

Fig. 10. Thickness strains along the expanded hole edge at a punch stroke of $28 \mathrm{~mm}$, compared with the FEA results (DH model)

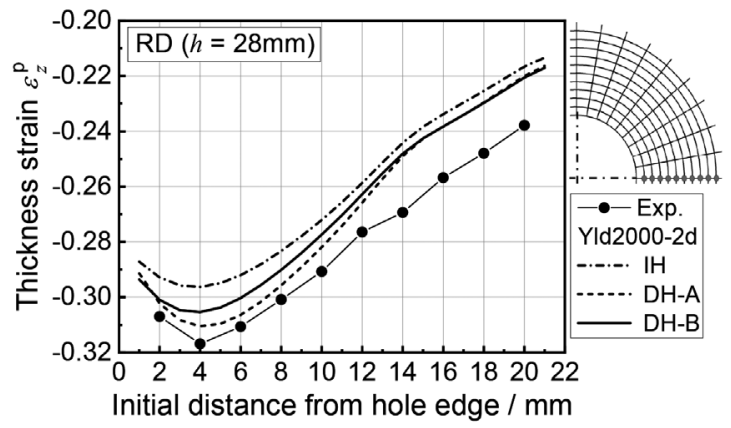

(a)

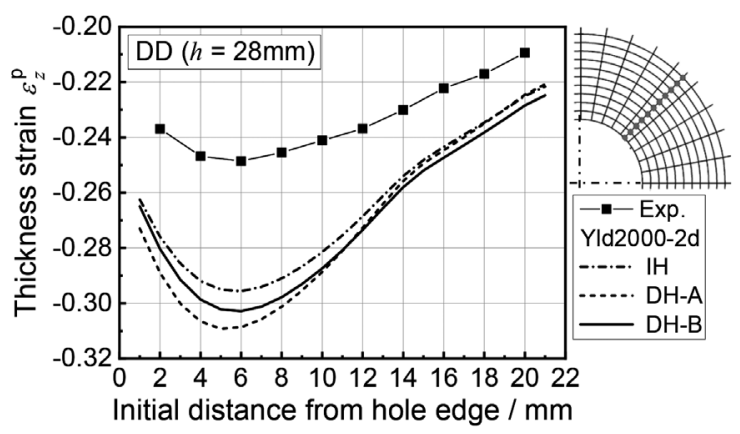

(b)

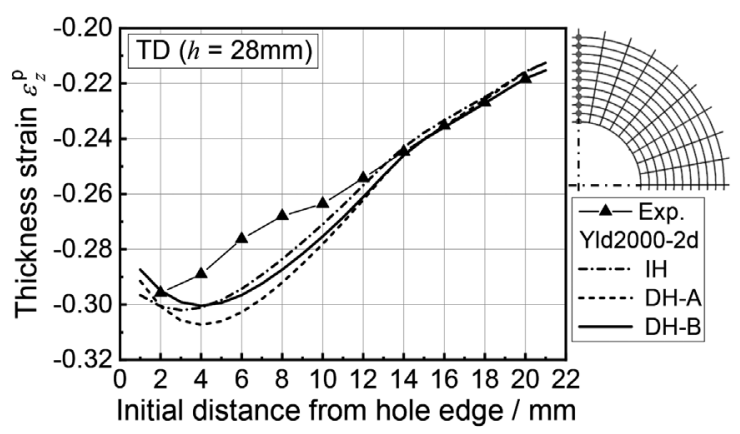

(c)

Fig. 11. Measured and calculated thickness strains along RD, $\mathrm{DD}$, and TD at a punch stroke of $28 \mathrm{~mm}$ (DH model). 
DH-B は実験值の傾向を精度よく再現できている。穴縁は 単軸引張応力状態であるので， $\sigma_{\theta}$ の発展の再現精度に優れ た DH モデルが $\mathrm{IH}$ モデルよりも穴縁近傍の $\varepsilon_{z}^{\mathrm{p}}$ の発達の予測 精度が向上したものと推測する。実際，穴広げ試験におい てさらにパンチを上昇させたところ，Fig.13に示すように， $h=32 \mathrm{~mm}$ において RDの穴縁より内側の位置で素板が破 断した。これより，RDにおいて $\varepsilon_{z}^{\mathrm{p}}$ が最小值をとることを的 確に再現したDHモデルは伸びフランジ成形の破断予測に 有効であると考える。この結果は文献18）打よび24）で得 られた知見とも整合する。

一方, $\mathrm{DH}$ モデルをもってしても, DD半径方向の板厚減 少が $0.02 \leq \Delta \varepsilon_{z}^{\mathrm{p}} \leq 0.06$ の範囲で過大に予測され，RD，TDよ りも実験值との乘離が大きくなった (Fig.11（b)）。これは 作成した材料モデルが依然として完璧ではないことを意 味する。本研究では, $\sigma_{x}-\sigma_{y}$ 平面応力空間に打ける等塑性 仕事面と $\mathbf{D}^{\mathrm{p}}$ の方向，ならびに穴縁近傍の変形状態と応力 状態を代表する $r_{\theta}$ と $\sigma_{\theta}$ の分布の再現精度を高めるように Yld2000-2dのパラメータを決定した。一方，材料モデルの 高精度化のためには $\sigma_{x}-\sigma_{y}-\sigma_{x y}$ 空間における 3 次元形状 の降伏曲面および $\mathbf{D}^{\mathrm{p}}$ の発展をくまなく高精度に再現する 必要があるが，上記の材料試験のみでは，降伏曲面の発展 を十分に捕捉できていない可能性がある。その対策とし て，以下に述べるような材料試験を追加で実施することが 有効と考える。本供試材の異方性は比較的小さいことか ら，議論の簡単化のために等方性材料を仮定する。このと

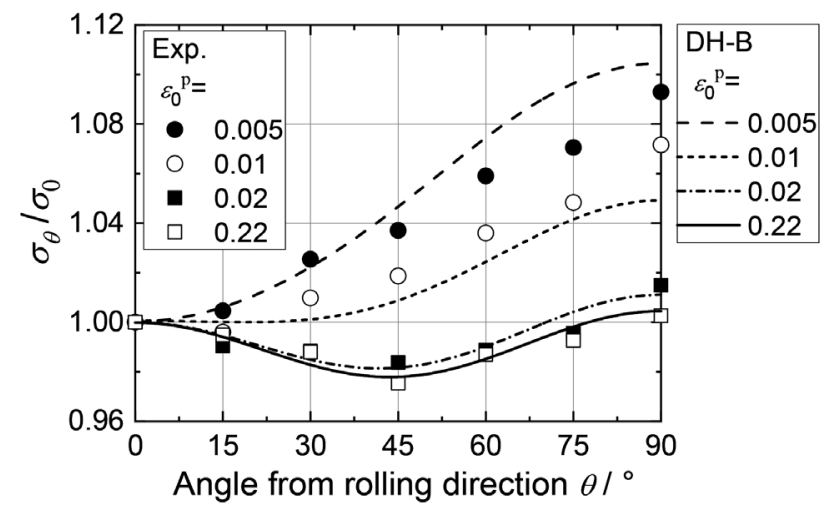

Fig. 12. Variation of $\sigma_{\theta} / \sigma_{0}$ with the increase of $\varepsilon_{0}^{\mathrm{p}}$, compared with that calculated using the DH-B model.

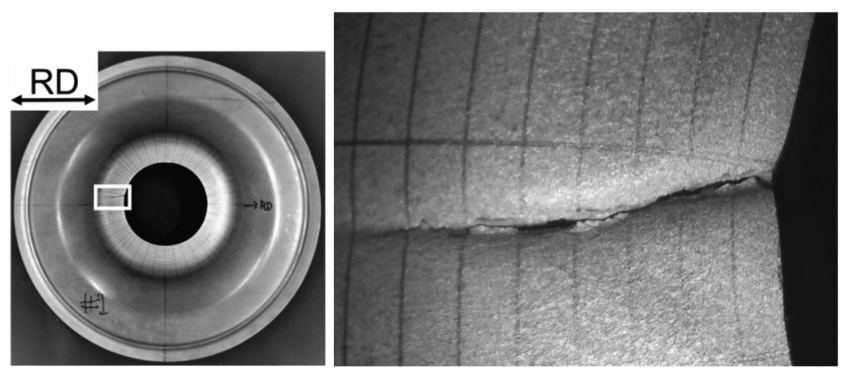

Fig. 13. Top view of a specimen with the fracture in the $\mathrm{RD}$ at the hole edge.
き，穴広げ成形において DDに沿う応力状態は， $\sigma_{x}-\sigma_{y}-$ $\sigma_{x y}$ 空間では $\sigma_{x}=\sigma_{y}$ 平面上に載る。これらの応力状態を再現 するためには，十字形試験片の腕方向を DDに平行に採り， 応力比を変化させて二軸引張試験を行えばよい。こうして 得られたDDの塑性変形特性をも再現できる材料モデルを 構築できれば, DDの板厚分布の計算值はより実験值に近 づく可能性がある。 $\sigma_{x}-\sigma_{y}-\sigma_{x y}$ 空間における降伏曲面の発 展を測定する他の方法としては，穴縁からある程度離れた 位置における変形モードの代表として, 応力の主軸方向を 幾通りかに変化させて平面ひずみ引張試験（主ひずみ増分 比 $\left.\dot{\varepsilon}_{1}^{\mathrm{p}}: \dot{\varepsilon}_{2}^{\mathrm{p}}=1: 0\right)^{32)}$ を実施する方法も考えられる。

\section{6. 結論}

$440 \mathrm{MPa}$ 級熱間圧延鋼板の二軸応力試験を行い, 異方硬 化挙動を精密に測定し，IH モデルに加えて異方硬化挙動を 再現する 2 種類の DH モデルを作成した。作成した 3 種類の 材料モデルを用いて穴広げ成形シミュレーションを行い, 計算值と実験值を比較することにより，材料モデルが成形 シミュレーションの解析精度に及ぼす影響を評価した。そ の結果，以下の知見を得た。

(1) $\sigma_{x}-\sigma_{y}$ 平面応力空間 $\left(\sigma_{z}=0\right)$ の第一象限に対して,9つ の線形応力経路を付与した二軸応力試験による等塑性 仕事面と $\mathbf{D}^{\mathrm{p}}$ の方向の測定結果，およびRDから $15^{\circ}$ 毎の 単軸引張試験結果から, 本供試材の異方硬化挙動を定 量的に評価した。

(2) Yld2000-2d の次数 $M$ および未知係数 $\alpha_{i}(i=1 \sim 8)$ の発 展を $\varepsilon_{0}^{\mathrm{p}}$ の関数として表現することにより, $\mathrm{DH}$ モデル を作成した。

（3）（2）で作成したDHモデルを穴広げ成形シミュレーショ ンに導入することで, RDに打いて $\varepsilon_{z}^{\mathrm{p}}$ が最小となる実験 值の傾向を的確に再現できた。ゆえに，伸びフランジ 成形における破断予測の高精度化には，異方硬化挙動 を再現できる材料モデルの使用が有効である。

（4）材料モデルのさらなる高精度化のためには, $\sigma_{x}-\sigma_{y}-$ $\sigma_{x v}$ 空間における3 次元形状の降伏曲面および $\mathbf{D}^{\mathrm{p}}$ の発展 をくまなく高精度に再現する必要がある。そのために は, 以下のような材料試験を追加実施し，得られた塑 性変形特性をも再現できる材料モデルを構築すること が有効と考える：（i ）十字形試験片の腕方向をDDに 平行に採り, 応力比を幾通りかに変化させて二軸引張 試験を行う；（ii）応力の主軸方向を幾通りかに変化さ せて平面ひずみ引張試験（主ひずみ増分比 $\left.\dot{\varepsilon}_{1}^{\mathrm{p}}: \dot{\varepsilon}_{2}^{\mathrm{p}}=1: 0\right)$ を実施する。

\section{謝辞}

供試材をご提供頂いた乃万暢賢博士 (ユニプレス株式会 社）に深甚なる謝意を表します。 


\section{文献}

1 ) M.Takahashi: J. Jpn. Soc. Technol. Plast., 58(2017), 105 (in Japanese). https://doi.org/10.9773/sosei.58.105

2 ) E.Iizuka, T.Hira and A.Yoshitake: J. Jpn. Soc. Technol. Plast., 46(2005), 625 (in Japanese).

3 ) F.Barlat and T.Kuwabara: J. Jpn. Soc. Technol. Plast., 57(2016), 230. https://doi.org/10.9773/sosei.57.230

4 ) H.Kurosaki and Y.Unno: Trans. Jpn. Soc. Mech. Eng. C, 51(1985), 409 (in Japanese). https://doi.org/10.1299/kikaic.51.409

5 ) H.Kurosaki, M.Tokiwa and K.Murai: Trans. Jpn. Soc. Mech. Eng. C, 52(1986), 380 (in Japanese). https://doi.org/10.1299/kikaic.52.380

6 ) M.Gotoh, C.-R.Lim and M.Misawa: Trans. Jpn. Soc. Mech. Eng. C, 59(1993), 2855 (in Japanese). https://doi.org/10.1299/kikaic.59.2855

7 ) H.Takuda, K.Mori, M.Kaneshiro and N.Hatta: Tetsu-toHagané, 84(1998), 182 (in Japanese). https://doi.org/10.2355/ tetsutohagane1955.84.3 182

8 ) H.Takuda, T.Ozawa, T.Hama, T.Yoshida and J.Nitta: J. Jpn. Soc. Technol. Plast., 49(2008), 886 (in Japanese). https://doi.org/10.9773/ sosei.49.886

9 ) M.J.Worswick and M.J.Finn: Int. J. Plast., 16(2000), 701. https://doi. org/10.1016/S0749-6419(99)00069-8

10) ISO 16842: 2014, Metallic materials -Sheet and strip -Biaxial tensile testing method using a cruciform test piece.

11) T.Kuwabara, S.Ikeda and T.Kuroda: J. Mater. Process. Technol., 8081(1998), 517. https://doi.org/10.1016/S0924-0136(98)00155-1

12) T.Kuwabara and F.Sugawara: Int. J. Plast., 45(2013), 103. https://doi. org/10.1016/j.ijplas.2012.12.003

13) T.Kuwabara, M.Umemura, K.Yoshida, M.Kuroda, S.Hirano and Y.Kikuta: J. Jpn. Inst. Light Met., 56(2006), 323 (in Japanese). https://doi.org/10.2464/jilm.56.323

14) T.Moriya, T.Kuwabara, S.Kimura and S.Takahashi: J. Jpn. Soc Technol. Plast., 51(2010), 43 (in Japanese). https://doi.org/10.9773/ sosei.51.43

15) T.Kuwabara, K.Hashimoto, E.Iizuka and J.W.Yoon: J. Mater Process. Technol., 211(2011), 475. https://doi.org/10.1016/ j.jmatprotec.2010.10.025

16) K.Hashimoto, T.Kuwabara, E.Iizuka and J.W.Yoon: Tetsu-toHagané, 96(2010), 557 (in Japanese). https://doi.org/10.2355/ tetsutohagane. 96.557

17) D.Yanaga, T.Kuwabara, N.Uema and M.Asano: Int. J. Solids Struct., 49(2012), 3488. https://doi.org/10.1016/j.ijsolstr.2012.03.005

18) T.Suzuki: Ph.D. thesis, Hiroshima University, (2018), (in Japanese), http://ir.lib.hiroshima-u.ac.jp/00046059, (accessed 2020-03-12).

19) R.Hill and J.W.Hutchinson: J. Appl. Mech., 59(1992), S1. https://doi. org/10.1115/1.2899489

20) R.Hill, R., S.S.Hecker and M.G.Stout: Int. J. Solids Struct., 31(1994), 2999. https://doi.org/10.1016/0020-7683(94)90065-5

21) T.Kuwabara, H.Takizawa and T.Hakoyama: J. Jpn. Soc. Technol. Plast. 57(2016), 181 (in Japanese). https://doi.org/10.9773/sosei.57.181

22) T.Yanaga, H.Takizawa and T.Kuwabara: J. Jpn. Soc. Technol. Plast., 55(2014), 55 (in Japanese). https://doi.org/10.9773/sosei.55.55

23) J.Kawaguchi T.Kuwabara and T.Sakurai: J. Jpn. Inst. Light Met., 65(2015), 554 (in Japanese). https://doi.org/10.2464/jilm.65.554

24) T.Kuwabara, T.Mori, M.Asano, T.Hakoyama and F.Barlat: Int. J. Plast., 93(2017), 164. https://doi.org/10.1016/j.ijplas.2016.10.002

25) T.Hakoyama and T.Kuwabara: From Creep Damage Mechanics to Homogenization Methods, ed. by H.Altenbach, T.Matsuda and D.Okumura, Springer, Heidelberg, (2015), 67. https://doi. org/10.1007/978-3-319-19440-0 4

26) F.Barlat, J.C.Brem, J.W.Yoon, K.Chung, R.E.Dick, D.J.Lege,
F.Pourboghrat, S.-H.Choi and E.Chu: Int. J. Plast., 19(2003), 1297. https://doi.org/10.1016/S0749-6419(02)00019-0

27) H.Tsutamori, E.Iizuka, T.Amaishi, K.Sato, Y.Ogiwara and J.Miyamoto: J. Jpn. Soc. Technol. Plast., 57(2016), 245 (in Japanese). https://doi.org/10.9773/sosei.57.245

28) Y.Hanabusa, H.Takizawa and T.Kuwabara: J. Mater. Process. Technol., 213(2013), 961. https://doi.org/10.1016/j.jmatprotec.2012.12.007

29) Y.Hanabusa, H.Takizawa and T.Kuwabara: Steel Res. Int., 81(2010), 1376.

30) R.v.Mises: Göttingen Nachrichten, Math.-phys. Klasse, (1913), 582 (in German). http://eudml.org/doc/58894, (accessed 2020-01-11).

31) R.Hill: Proc. Roy. Soc. Lond. A, 193(1948), 281. https://doi. org/10.1098/rspa.1948.0045

32) T.Kuwabara and S.Ikeda: Tetsu-to-Hagané, 88(2002), 334 (in Japanese). https://doi.org/10.2355/tetsutohagane1955.88.6_334

\section{附録}

\section{DH-AおよびDH-Bモデルの近似式のパラメータ}

4節にて作成したDH-A モデルに用いた近似式 (2)，(3) のパラメータを Table A1に, DH-Bモデルに用いた近似式 (4) のパラメータを Table A2に示す。なお，DH-Aの $\alpha_{5}$ お び $\alpha_{7}$ に関してはひずみの進展による変化が小さかったた め平均值を取り一定とした。

Table A1. Parameters of DH-A model

\begin{tabular}{c|c|c|c|c}
\hline & $A$ & $B$ & $C$ & $D$ \\
\hline$M^{*}$ & 6.295 & 8.1383 & 0.0521 & 0.0284 \\
\hline$\alpha_{1}{ }^{* *}$ & 0.9882 & 0.1343 & 55.849 & -0.0009 \\
\hline$\alpha_{2}{ }^{* *}$ & 0.4932 & -0.4932 & 0.0019 & -0.0010 \\
\hline$\alpha_{3}{ }^{* *}$ & 0.5137 & -0.5141 & -0.0233 & 0.0008 \\
\hline$\alpha_{4}{ }^{* *}$ & -5.6693 & -6.682 & -0.001 & 0.0004 \\
\hline$\alpha_{5}{ }^{* *}$ & 1.0065 & 0 & & 0 \\
\hline$\alpha_{6}{ }^{* *}$ & -15.318 & -16.269 & -0.0011 & -0.0007 \\
\hline$\alpha_{7}{ }^{* *}$ & 1.0145 & 0 & & 0 \\
\hline$\alpha_{8}{ }^{* *}$ & 1.0450 & 0.2079 & 108.236 & 0.0000 \\
\hline
\end{tabular}

* Approximated using $M\left(\varepsilon_{0}^{\mathrm{p}}\right)=(A-B) /\left[1+\exp \left\{\left(\varepsilon_{0}^{\mathrm{p}}-C\right) / D\right\}\right]+B$ (Eq.(2))

** Approximated using $\alpha_{i}\left(\varepsilon_{0}^{\mathrm{p}}\right)=A-B \exp \left(-C \varepsilon_{0}^{\mathrm{p}}\right)-D /\left(0.001+\varepsilon_{0}^{\mathrm{p}}\right)($ Eq. $(3))$

Table A2. Parameters of DH-B model.

\begin{tabular}{c|c|c|c|c}
\hline & $A$ & $B$ & $C$ & $D$ \\
\hline$M^{*}$ & -7.4392 & -21.886 & -53.627 & 7.3412 \\
\hline$\alpha_{1}{ }^{*}$ & -74.845 & 3.6662 & -574.46 & 1.0005 \\
\hline$\alpha_{2}{ }^{*}$ & -8.4133 & -38.792 & -445.17 & 0.9623 \\
\hline$\alpha_{3}{ }^{*}$ & -6.6872 & -25.681 & -344.42 & 0.9982 \\
\hline$\alpha_{4}{ }^{*}$ & 21.854 & 3.4405 & -254.58 & 1.0098 \\
\hline$\alpha_{5}{ }^{*}$ & 2.6582 & -6.4287 & -380.71 & 1.0163 \\
\hline$\alpha_{6}{ }^{*}$ & -147.99 & 2.0058 & -747.27 & 1.0301 \\
\hline$\alpha_{7}{ }^{*}$ & 17.786 & 2.5921 & -258.14 & 1.0238 \\
\hline$\alpha_{8}{ }^{*}$ & 29.91 & 4.3286 & -378.23 & 1.0292 \\
\hline
\end{tabular}

*Approximated using $M, \alpha_{i}(i=1 \sim 8)=A \varepsilon_{0}^{\mathrm{p}}\left(\varepsilon_{0}^{\mathrm{p}}-B\right) \exp \left(C \varepsilon_{0}^{\mathrm{p}}\right)+D$ (Eq.(4)) 